\title{
The Repair of Civil Developments with Environmental Compensation: An Analysis in Brazilian the Court of Superior Based on Special Appeal 896.863
}

\section{Carolina Mirandaprado $\mathbf{M}^{*}$}

Master in Environmental Law, Specialist in labor law \& Civil Law, Institute of Continuing Education, Brazil

*Corresponding author: Carolina Miranda Mirandaprado, Master in Environmental Law and Sustainable Development by ESDHC. Specialist in labor law from ESA of OAB/MG. Specialist in Civil Law by the IEC of PUC-Minas, Bachelor of Laws from ESDHC, Lawyer, Institute of Continuing Education, Brazil, Email: carolina.mascarenhas@yahoo.com.br

\section{Mini Review}

Volume 4 Issue 1

Received Date: February 24, 2021

Published Date: March 15, 2021

DOI: $10.23880 /$ abca-16000167

\section{Abstract}

This article analyzes the Special Appeal (Resp) No 896863-DF in the Superior Court of Justice (STJ) defines the non-occurrence of bis in idem when even with the implementation of an environmental compensation the degrading is sentenced to repair civilly damage caused by your enterprise. This analysis will unfold in the definition of environmental responsibility in the Brazilian law and forms of civil damages the environment. It will be observed that the environmental compensation has the distinct nature of civil damages, each institute applied due to pipelining by facts that have no connection. Through deductive methodology with theoretical and documentary research, verify that the rules of substantive law adequately serve the purpose of civil remedies and do not have the same purpose of environmental compensation. However, it is still addressed the deficiency of judicial protection due to the lack of specific procedures and consistent to environmental protection, especially in relation to the liquidation of environmental damage.

Keywords: Civil liability; Environmental compensation; Damage Repair; Damage of liquidation

\section{Introduction}

The principles and rules applicable to the material law for making the degrader liable do not leave room for uncertainty about the proper application of civil sanctions in the repair and/or restoration of the environmental asset.

As will be presented, in the view of several indoctrinators, civil liability can have different functions and effects, among which are the repair to obtain the cessation or reduction of a loss, the suppression of a harmful situation or fact to cease the activity that is it is at the origin of the damage and the civil penalty to apply a sanction as a result of commissive or omissive conduct. In addition, civil liability may have ancillary functions as a deterrent to unlawful behavior and to prevent other damages, acting on the conduct of the person responsible.

In the present study, a specific case based on REsp 896.863-DF will be specifically analyzed, in which the objective liability of the degraders was observed and civil penalties for recomposition and compensation for the damages caused were applied, even though there was previously the fulfillment of environmental compensation for the realization of their activities with this, it will be discussed that even if there is a licensing for the execution of works and the previous determination of environmental compensation for the installation of a project, the degrader may be held responsible for any damages caused by his 
project, regardless of whether there was evidence of fraud or the fault of the degrader.

Thus, with the differentiation of the forms of civil reparation, you can observe thatenvironmental compensation is not to be confused with a form of civil reparation, given that the legal nature and purposes are different and yet, with a brief presentation of the procedural phase for the settlement of the environmental damage, even with all the guarantees provided for in the applicable legislation, it will be verified that effective remedial protection is not achieved, if the fundamental objectives of civil reparation are not fulfilled. Even checking the current procedural principles and rules, it is noted that there are still no procedural rules capable of meeting the specifics of environmental protection.

\section{Brief Analysis of the Concrete Case Concerning the Special Feature 896.863-DF}

The present case refers to the legal discussion about the possibility or not of fixing reparations and indemnities for possible environmental damages, even when environmental compensation is complied with. The Public Ministry of the Federal District filed a public civil lawsuit against the Government of the Federal District and two companies that execute public services in carrying out earthworks and paving public roads.

The aforementioned public civil action aimed at repairing reversible damages and indemnity for irreparable damages arising from the construction of the HI-60 road and the bridge over the Cabeça-de-Veado stream which resulted in the removal of vegetation and modification of the permanent preservation area, in obstacles to the free movement of animals in the conservation unit, they also caused negative impacts such as the interruption of the ecological corridor, which generated several negative impacts on the ecosystem. In the first instance, the Government of the Federal District and only one company were condemned for the requests made in the exordial, since the other company was only the executor of the services. In the first appeal phase, the court of origin dismissed the appeals.

In the special appeal, the Appellants alleged that it was not possible to condemn the restoration of the affected area and not even indemnity for environmental damage, considering that the environmental compensation previously established had been fulfilled and that in this way it would be doubly penalizing the Appellants for a situation that it was supposed to be resolved.

As Minister Rapporteur Castro Meira emphasized in his vote, there is no need to talk about the occurrence of bis in idem in that situation, as they are different institutes, with totally different purposes.

It also explains that environmental compensation is defined even before the occurrence of any damage and that it occurs through lawful conduct, based on previous studies of environmental impact. In turn, civil reparation will occur for the occurrence of the damage through an illegal act and is defined precisely by the fact that the damage goes beyond the limits provided for in the previous analysis instruments, such as the Environmental Impact Study (EIA) or the Environmental Impact Report (RIME).

It was also emphasized that the civil liability for environmental damage is objective, that is, it does not depend on the offender's proof of guilt, with only the damage and causal link to be proved, which occurred in the specific case. In this sense, the Ministers of the Second Panel of the STJ judged, unanimously, the rejection of the Special Appeal for not finding sufficient grounds for its merit in view of the understanding adopted.

Thus, based on the case in question, the notions brought by the doctrine in relation to the aforementioned institutes will be addressed in this article, having previously studied civil liability and its implications.

\section{Environmental Civil Responsibility}

The general objective of civil repair of the environment is to compensate for the damage caused to environmental quality as an intangible asset of a collective nature and we always seek to privilege a repair closer to the previous state, always trying to return all lost environmental wealth.

Although subjectivist civil liability prevails as a general rule in the Civil Code, what can be noted is that in environmental matters the choice of the legislator and the constituent was to apply the strict civil liability rules. Thus, when civil liability is objective, it is verified that it will not be necessary to prove the existence of guilt for the occurrence of the damage, taking into account the difficulty of proving guilt in degrading activities to the environment. For this reason, it will only be necessary to prove the damage and the causal link of the damage in relation to the conduct adopted by the degrader [1].

What can be observed is that the environmental civil liability has its own system regulated by the provisions of article 225, $\S 3$ of the Constitution of the Republic and of articles 4, VI, VII, 14, §1 of Law 6.938/81, thus removing, the application of the general rules of the Civil Code, becoming a microsystem of civil liability. It is worth mentioning that as a result of strict civil liability, it will be understood that even with the fulfillment of all legal determinations and 
environmental requirements, the offender will be held responsible for the risks and / or damages caused to the environment.

\section{Theory of Integral Risk and Theory of Risk Created}

In order to define liability for civil damages, there is in the doctrine the definition of several theories about how the damage will be approached to arrive at the degradator's liability framework. And to better exemplify this, the two main theories about the configuration of this civil liability for environmental damages will be addressed.

The first to be addressed is the theory of integral risk in which it admits the responsibility of the cause of the damage from the moment when it develops a potentially degrading activity, without needing proof that this activity had a direct influence on the occurrence of the damage. The degrader fully assumes the risks of his enterprise when he is ready to develop it and, therefore, all the damage derived from his activity must be repaired, regardless of whether there is a direct influence on the occurrence of the damage.

Some indoctrinators will justify this theory on the grounds that when carrying out an activity the person assumes unlimited bonuses, so why would there be limits to the burden that his activity can cause? All of these are risks that were taken when starting the development of the activity.

\section{Ferraz cited by Bredan; Mayer demonstrates his position in line with the theory:}

There should be no major concern in relating the agent's activity to the loss. It is enough that, potentially, the agent's activity may cause ecological damage for the burden of proof to be immediately reversed, so that the presumption of responsibility is immediately produced, thus reserving, for the eventual triggered, the burden of seeking to exclude its imputation [1] and in that sense, Mirra conceptualizes that comprehensive repair "must understand not only the damage caused to the environmental good or resource attained, but also, in Helita Barreira Custódio's lesson, the entire extent of the damage produced as a result of the harmful fact [...]" [2].

The use of this theory is in order to ensure that the damage is repaired as closely as possible to the status quo ante, minimizing all the effects and consequences resulting from human interference. In several STJ judgments, the recognition of the application of this theory has already been pacified and, therefore, there is no doubt that at the moment of verifying the responsibility of the cause of the environmental damage, he will be fully responsible for all the damages caused.
However, in a minority way, some do not agree with the application of integral risk, and for that reason, they defend the theory of created risk that is based on the conception that the development of a potentially harmful or dangerous activity, which generates risks to a harmful event, will be able to generate accountability for those who exercise it.

\section{Stoco develops the following definition:}

The theory of risk created is one in which the agent responds because of the risk or danger that the activity performed presents, that is, one that, because of his activity or profession, creates a danger or exposes someone to the risk of damage. In this theory the responsibility is not connected to a profit or profit, but only to the consequence of the activity in general, so that the idea of risk starts to connect to any human activity that is potentially harmful to others, as in the prediction of art. 927 of CC [3].

Based on this theory, damage is not expected to take place, attitudes are already taken before its occurrence, and those who bring risks to some asset are held civilly responsible. Thus, the equity provisions contained in the sole paragraph of Article 944 of the Civil Code are totally inapplicable.

\section{Principles Applicable to Environmental Civil Repair}

In order to seek the most appropriate protection possible for the environment, some principles are observed at the moment of the responsibility of those who cause some environmental damage. Among them, there is the principle of prevention that aims to protect the environmental good even before the occurrence of the actual damage, thus allowing those who generate risks to the degradation of the environment to be held responsible.

Sampaio points out that "Prevention is the way to anticipate environmental degradation processes, through the adoption of management and protection policies for natural resources" [4].

\section{For Fiorillo, the prevention principle has the following basis:}

[...] The Magna Carta established an imposition on both the Public Power and the community not only in the defense of the goods indicated in that constitutional provision - those goods considered essential to the healthy quality of life of the human person, as already stated - but also to the preservation of goods environmental issues [5].

Another important principle, to be observed at the time of civil repair, is the polluter pays principle that determines the degrader the obligation to assume the costs of its activity 
and for that reason it must internalize all the costs arising from the conservation and recovery of the environment degraded by its activity. As already seen, the environmental civil repair has as its first objective to restore the environment to its status quo ante, and if it is not possible, it will seek the closest possible form to its previous state, being in the last case, seek compensation, a repair monetary compensation, in compensation for the damage caused.

Therefore, for the civil repair of environmental damage, there are two ways: in nature repair and pecuniary repair, which are means of compensating the damage in which the main difference between them is their respective efficiency, which may give a better adaptation to the restoration and compensation for damage to the environment.

\section{Ways to Repair Environmental Damage}

As already mentioned, in nature repair is the most efficient means of restoring the degraded environment and is based on the determination of an obligation to do to the degrader. The aim is to bring the same functional capacity or as close as possible to the degraded asset.

Mirra states that: "With regard to environmental damage, the repair in nature appears as an appropriate and even indispensable way of its full compensation" [2].

What has prevented a greater application to this means of repair is the high cost of establishing a recovery plan for the degraded area, which can often cost the entire property of the degrader or even more, in this way, proportionality is applied and the other type of repair ends up being adopted within the limits possible to the degrader's assets.

Although it is the most efficient means of repairing environmental damage, this form of repair is not applied in all cases, precisely because it is always considered the economic capacity of the degrader, with its assets being the limit of the repair. The pecuniary reparation is a subsidiary modality to repair the environmental damage; however it has been the most used. In a first plan, it is linked to the damages susceptible to economic evaluation, since its objective would be to replace what was lost and to compensate for what was not gained.

However, the environmental good has no monetary equivalence and for that reason it becomes an immaterial good, therefore, it is only subject to economic compensation and this means the impossibility of evaluating the damage caused in cash and to resolve this impasse, the legislator ended up opting to allow the accumulation of pecuniary reparations with some obligation to do or not to do, as provided in article 3 of Law 7347/85.

\section{Environmental Compensation}

Environmental compensation is not a form of civil reparation and is established and regulated by Law $9985 / 2000$ and Decree $4.340 / 2002$, which was amended by Decree No. 6848/2009.

It refers to the implementation of a conservation unit in the public domain and indirect use as a way to compensate for the environmental impacts that a given enterprise will cause in its installation. As provided in art. 36, caput and $\S 3$ of Law 9985/2000, the compensation will be defined even before the implementation of the project and will be defined according to previous studies and reports of the EIA/ RIMA: Art. 36. In cases of environmental licensing of undertakings with significant environmental impact, thus considered by the competent environmental agency, based on an environmental impact study and respective reportEIA/RIMA, the entrepreneur is obliged to support the implantation and maintenance of the unit conservation of the Comprehensive Protection Group, in accordance with the provisions of this article and the regulation of this Law [...].

$\S 3$ When the undertaking affects a specific conservation unit or its buffer zone, the licensing referred to in the caput of this article may only be granted upon authorization from the body responsible for its administration, and the affected unit, even if it does not belong to the Group Comprehensive Protection, must be one of the beneficiaries of the compensation defined in this article.

In the decision analyzed in this article, Reporting Minister Castro Meira clearly made this distinction between environmental compensation and civil reparation:

- [...] The compensation has a reparatory content, in which the entrepreneur devotes a considerable part of his efforts to actions that serve to counterbalance the use of natural resources that are indispensable for the realization of the enterprise foreseen in the environmental impact study and duly authorized by the competent agency.

- The amount of the compensation must be limited to those inevitable and essential damages to the undertaking provided for in the EIA/RIMA, not including those that may be the object of mitigating or preventive measures.

- The indemnity for environmental damage, in turn, is based on Article 225, § 3, of the Charter of the Republic, which deals with the hypothesis of damage that has already occurred, in which the plaintiff will have the obligation to repair it or indemnify the community. There is no way to include in that context the one foreseen and authorized by Organs environmental agencies already duly compensated [...] [6]. 
It is true that the legal nature of environmental compensation has brought some discussions to the legal environment. For a time there was even confusion about its classification as a form of civil reparation. For this reason, it is important to be clear about the differentiation brought by Law 9985/2000 in its art. 2nd:

2nd. for the purposes provided for in this Law, it is understood by: [...]

XIII-recovery: restoring an ecosystem or a degraded wild population to an undegraded condition, which may be different from its original condition?

XIV-restoration: restoring an ecosystem or a degraded wild population as close as possible to its original condition.

It is noted that the difference between the two terms explained above is due to the determination of the original condition that will be possible in only one case, that is, in restoration. However, what cannot be departed from in common between both terms is that they refer to forms of civil reparation that do not include environmental compensation. There are still those who defend the remedial nature of this institute, but the STF has established its understanding that environmental compensation does not have a remedial nature, therefore being a way of sharing expenses in the prevention of environmental impacts [7].

Therefore, environmental compensation cannot be confused as a form of civil reparation, as it is implemented as a result of a lawful act, such as the installation of a project that meets the requirements for the exercise of its activity, and civil reparation occurs before the occurrence of an illegal act, the occurrence of environmental damage.

It is important to highlight that another distinguishing point of environmental compensation for civil repair is the moment and the means of defining its application. As previously seen, environmental compensation applies to a lawful activity, before the damage occurs and, therefore, is defined through an administrative inspection process, without the Judiciary's action. Civil reparation for illicit activity that causes environmental damage, however, requires the Judiciary to act in order to define the most appropriate and possible form of civil reparation for the specific case.

Thus, questions related to the environmental judicial process will be analyzed below, mainly regarding the damage settlement phase, as it is the instrument that will seek the due civil repair and the moment to determine which form will be the most appropriate to recover the environment.

\section{The Environmental Process}

Unlike what was seen in relation to material law, there is no specific procedural system specific to environmental protection, thus, general rules of the current procedural order apply. For this reason, when it comes to individual protection of the environment, the procedural rules of the Civil Procedure Code in force are applied.

As a result, there is often no adequate procedural protection for the environmental good due to the difficulty in applying procedural rules to ensure better protection, since they were not created under the same focus as specific environmental protection standards with regard to collective redress, the Brazilian legal system has slightly more specific rules on the matter and for this reason the Civil Procedure Code ends up having subsidiary application. In prevalence in the application of procedural rules for collective protection of the environment, there is Law 7347/85 (Law of Public Civil Action) [8] and Law 8078/90 (Consumer Protection Code) [9], subsidiarity applying the Code Civil Procedure and Law 4717/65 (Law of Popular Action) when there is no incompatibility.

Even so, the procedural provisions in force often do not reveal the necessary efficiency for the protection of the environment, causing an excessive delay for the due repair as soon as possible.

\section{Principles Applicable to the Environmental Process}

In addition to the principles applicable to the material law of the environment, it is necessary to observe and apply some principles in the procedural phase of protection and repair to the environment to ensure effective judicial provision.

In this sense, it is important to first emphasize the principle of broad access to jurisdiction, which is very important in the collective protection of environmental rights and which is not limited only to the right of action, but also refers to the right of defense, to refute a claim in court, and also, protection of the collective interest with the expansion of procedural instruments another relevant principle for the procedural phase is the principle of equality, but real or substantial equality, which according to the STF's understanding refers to equal treatment and unequal treatment to unequal ones, to the extent of their inequality. This principle is important precisely for collective redress, since it is based on it that the application of article 6, VIII of the Consumer Protection Code is allowed, in which the reversal of the burden of proof is guaranteed in the proceedings that have the object of redress to the environment and also the expansion of the powers of the judge that involves a new judicial stance in search of real equality.

The principle of reasonable duration of the process also has great relevance to the environmental process and 
means to ensure a duration of the process that guarantees a speed capable of giving effectiveness to the judicial provision within a sufficient time for the protection of the environment and not only based on the rules applicable procedural rules, but also on the basis of legal statements duly substantiated by solid reasons. According to Antônio Pacheco FC, et al. [5], this principle is important in the environmental process to prevent manifestations of a political or even ideological nature in order to justify the duration of the process.

The adversarial principle also applicable to the environmental lawsuit aims to guarantee the defendant the right to be informed about the existence and content of any judicial or administrative proceeding to his disadvantage, thus giving him the opportunity to defend himself in the way that best suits him in accordance with the law. Principle of broad defense and admissibility of evidence, which ensure the right of defense in the broadest, general and unrestricted manner, being able to use all the means and resources provided by law, always in compliance with the principle of due process Antônio Pacheco FC, et al. [5].

According to Antônio Pacheco FC, et al. [5], due to the guarantee of the application of the principles mentioned above, the defendant ends up being implicitly guaranteed the application of the principle of double degree of jurisdiction another important principle that involves more the damage settlement and execution of the sentence is the principle of obligation, in which it is verified that if the settlement or the execution is not started within 60 (sixty) days of res judicata, the Ministry The Public must do so within the following 30 (thirty) days, under penalty of serious misconduct. As provided in article 82 of the Consumer Protection Code, other legitimate ones have the power to give impetus to these phases, but the Public Ministry has the obligation to provide this continuity and these principles will be important in the damage settlement phase in order to provide the best possible support for any damages caused even during the judicial process.

\section{Settlement of Environmental Damage}

Once it is established that there has been an environmental damage and that it should be repaired, the damage settlement phase begins in order to carry out the condemnation imposed on the degrader. The settlement of environmental damage is not a simple matter to resolve, for this reason it would be important to establish some criteria to arrive at a final determination of quantification of the protected property.

In the Civil Procedure Code of 1973, there were two types of sentence settlement: by articles and by arbitration. In the new Code of Civil Procedure, the term settlement by articles ceased to exist, and settlement by the common procedure came to exist and maintaining settlement by arbitration.

Settlement by articles was provided for in Article 475E of the Civil Procedure Code of 1973 and occurred when there was a need to claim or prove a new fact, applying the common procedure where applicable, and with the advent of Law 11.232/05 it had been the process of executing a court order as an autonomous process is extinguished.

In the new Code of Civil Procedure, settlement by the common procedure also continues to be used when there is a need for allegation or proof of a new fact, however the 15 (fifteen) day challenge period has already been expressly established, which ended up not changing much the practice, as the application of the procedural rules of the Common Procedure was already observed (articles 509 and 511 of Law 13.105/2015) [10].

In turn, the settlement by arbitration provided for in Article 475-C of the 1973 Code of Civil Procedure took place by judicial determination [11-13], by convention of the parties or because of the object depended on expertise for its determination. The new Civil Procedure Code did not change much in relation to this form of liquidation, establishing the same hypotheses and a simpler procedure in relation to the old one. It turns out that such forms of settlement in isolation have not been sufficient for the environmental process, which cannot fail to consider the need to create its own procedural system, since environmental assets are complex and demand their own valuation criteria.

\section{Final Considerations}

Through the specific case referring to REsp 896.863, it is possible to analyze the entire civil liability system as a result of environmental damage. A clear understanding was established that the degrader's responsibility is objective, and there is no need to examine his culpability for the realization of the environmental damage. It can also be observed that, regardless of whether there was approval and licensing of the construction or project, the degrader will be held responsible for the damage caused to the environment and the regularity of his project is not enough to remove his responsibility $[14,15]$.

It was found that the environmental compensation institute cannot be confused as a form of civil reparation that its purpose and applicability occur at different times due to different conduct. Thus, environmental compensation takes place even before the occurrence of any damage and is based on a way to compensate for possible impacts resulting from the activities of the degrader. It was also noted that the environmental process, as an instrument to carry out 
the investigation of damage and the applicability of due repairs, is still deficient, not least because there is no proper procedural system for Environmental Law, different from what occurs in relation to the liability system. Civil society that has a specific microsystem [16-20].

Finally, it was verified that in order to arrive at an adequate repair of the environmental damage it is important that in the liquidation phase the possible forms of liquidation provided for in the CPC are applied concomitantly precisely in order to determine more fully all the damages caused.

\section{References}

1. Karina Marcos B, Elizabeth M (2013) Civil liability for environmental damage in Brazilian law and compared: Theory of Risk Created versus Theory of Integral Risk. Veredas do Direito, Belo Horizonte 10(19): 45-88.

2. Álvaro Luiz MV (2004) Public civil action and the repair of damage to the environment. $2^{\text {nd }}$ (Edn.), São Paulo: Juarez de Oliveira, Third part. Title I, Chapter 1-3, pp: 301-366.

3. Rui S (2007) Civil liability treaty: doctrine and jurisprudence. $7^{\text {th }}$ (Edn.), São Paulo: Editora Revista dos Tribunais, Title I. Chapter I.

4. Jose Adercio SL (2003) WOLD, Chris, NARDY, Afrânio. Principles of environmental law. Belo Horizonte: Del Rey, Second part. Chapter II, pp: 45-85.

5. Antônio Pacheco FC (2012) Principles of environmental procedural law. $5^{\text {th }}$ (Edn.), São Paulo: Saraiva.

6. Annelise Monteiro S (2011) Considerations on the causal link in civil liability for damage to the environment. In: Édis $\mathrm{M}$, et al. Environmental law: responsibility in environmental matters 5, pp: 43-74.

7. (2008) Federal Court of Justice. Full Court. ADI 3.378-6DF. Rel. Min. Carlos Britto, Brazil.

8. (1985) Law No. 7,347, Disciplines public civil action for liability for damages caused to the environment, to the consumer, to goods and rights of artistic, aesthetic, historical, touristic and landscape value (VETOED) and takes other measures, Brazil.

9. (1990) Law No. 8,078, Provides for consumer protection and other measures, Brazil.

10. Law No. 13,105, Civil Procedure Code, Brazil.

11. (1998) Constitution of the Federative Republic of Brazil 1988. Presidency of the Republic Sub-Sofia, Civil House for Legal Affairs, Brazil.

12. (1916) Law No. 3,071, Civil Code of the United States of Brazil.

13. (1981) Law No. 6,938, Provides for the National Environmental Policy, its purposes and mechanisms for formulation and application, and provides other measures.

14. (2000) Law No. 9,985, Regulates art. 225, § 1, items I, II, III and VII of the Federal Constitution, establishes the National System of Nature Conservation Units and provides other measures, Brazil.

15. (2002) Law No. 10,406, Institutes the Civil Code. Brazil.

16. (2011) Superior Justice Tribunal. $2^{\text {nd }}$ Class. Special Resource No. 896,863-DF, Brazil.

17. Galdino CVS, Camargo BH (2008) Ways of repairing environmental damage. Journal of Legal Sciences 6(2): 155-178.

18. Juliana G (2009) Settlement of a sentence for diffuse environmental damage. Collective Proceedings, Porto Alegre 1(1).

19. Edis M (2015) Environmental Law. $10^{\text {th }}$ (Edn.), Sao Paulo: Revista dos Tribunais.

20. Marcelo Abelha R (2011) Environmental Civil Procedure. $3^{\text {rd }}$ (Edn.), Paulo: Editora Revista dos Tribunais, Chapter 6, pp: 226-236. 